\title{
Inflammation in the male genital tract: implications for HIV acquisition and transmission
}

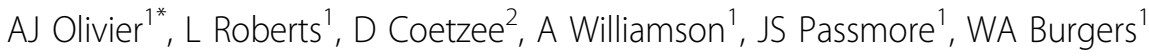 \\ From AIDS Vaccine 2012 \\ Boston, MA, USA. 9-12 September 2012
}

\section{Background}

Elevated plasma levels of pro-inflammatory mediators such as TNF $\alpha$, IL-1 $\beta$, IL-6 and IL-8, MIP- $1 \alpha$, MIP- $1 \beta$ and RANTES have been demonstrated in HIV-infected individuals and HIV induces higher levels of pro-inflammatory cytokines in the female genital tract. We characterized levels of inflammation in semen, to gain an understanding of factors influencing transmission and acquisition in the male genital tract. Our hypothesis was that infected men would exhibit higher levels of inflammation in semen than uninfected men.

\section{Methods}

We investigated concentrations of 20 pro-inflammatory and other mediators in the semen and blood of 38 HIVinfected and 42 uninfected men forming part of an HIV-discordant heterosexual couples study. We measured plasma and seminal viral loads to examine the relationship between viral replication and inflammation.

\section{Results}

We found that the majority of cytokines/chemokines were at higher concentrations in semen than blood, both in HIV-infected and uninfected men. There were no significant differences between any cytokines/chemokines in the semen of HIV-infected vs uninfected men. We found that TNF $\alpha(p=0.013 ; \mathrm{r}=0.55), \mathrm{G}-\mathrm{CSF}$ $(\mathrm{p}=0.0057 ; \mathrm{r}=0.61), \mathrm{IL}-10(\mathrm{p}=0.006 ; \mathrm{r}=0.61)$ and IFN $\gamma$ $(\mathrm{p}=0.01 ; \mathrm{r}=0.57)$ seminal levels were significantly associated with increases in seminal viral load. Furthermore, subsequent to controlling for the effect of plasma viral load in a multivariate regression analysis, we found that both seminal IL-10 and IFN $\gamma$ levels were associated with a significant rise in seminal viral load.

${ }^{1}$ IIDMM, Division of Medical Virology, University of Cape Town, Cape Town, South Africa

Full list of author information is available at the end of the article

\section{Conclusion}

Taken together, the data demonstrate that the immune milieu of the genital tract differs substantially from blood, with the majority of cytokines/chemokines tested elevated in semen. However, there were no differences in the levels of pro-inflammatory mediators in the semen of HIV-infected and uninfected men, or HIV-infected men on suppressive ART. Thus, even in the absence of HIV infection, the male genital tract appears to maintain a state of inflammation, which may have been the result of undetected and untreated co-infections.

\section{Author details}

${ }^{1}$ IIDMM, Division of Medical Virology, University of Cape Town, Cape Town, South Africa. ${ }^{2}$ Department of Public Heatlh, University of Cape Town, Cape Town, South Africa.

Published: 13 September 2012

doi:10.1186/1742-4690-9-S2-023

Cite this article as: Olivier et al: Inflammation in the male genital tract:

implications for HIV acquisition and transmission. Retrovirology 20129 (Suppl 2):O23.

Submit your next manuscript to BioMed Central and take full advantage of:

- Convenient online submission

- Thorough peer review

- No space constraints or color figure charges

- Immediate publication on acceptance

- Inclusion in PubMed, CAS, Scopus and Google Scholar

- Research which is freely available for redistribution

\section{Biomed Central}

